\title{
Effect of Paraquat on Tilapia Fingerlings under laboratory condition
}

\author{
*11NKEEH, DK; ${ }^{2}$ JAMABO, NA \\ ${ }^{I}$ Department of Environmental Technology and Management, World Bank Africa Centre of Excellence, Centre for Oilfield Chemicals \\ Research, University of Port Harcourt, Choba,P.M.B.5323, Rivers State, Nigeria, \\ ${ }^{2}$ Department of Fisheries, Faculty of Agriculture, University of Port Harcourt, Choba, P.M.B.5323, Rivers State, Nigeria \\ *Corresponding Author Email: kootedumbari@gmail.com
}

\begin{abstract}
A total of 150 fingerlings of Tilapia guinensis, were acclimated for a period of 14days. A static bioassay was used during the period of the experiment. Mortality was measured at different time intervals of $10 \mathrm{hr}, 12 \mathrm{hr}, 16 \mathrm{hr}, 20 \mathrm{hr}$, $46 \mathrm{hr}$ and $52 \mathrm{hr}$ for the range finding test, using different concentrations of paraquat $(120 \mathrm{mg} / 1,60 \mathrm{mgl}, 30 \mathrm{mg} / 1 \mathrm{and} 15 \mathrm{mg} / 1)$. Acute toxicity test, using different concentrations of paraquat $(10 \mathrm{mg} / 1,5 \mathrm{mgl}, 2.5 \mathrm{mg} / 1$ and $1 \mathrm{mg} / \mathrm{l})$ was used to measure mortality of 4, 0,0 and 0 respectively, for $96 \mathrm{hrs}$. The test established the $\mathrm{LC}_{50}(10 \mathrm{mg} / \mathrm{L})$ of paraquat on fingerlings of T.guinensis. Three sublethal treatments $(5 \mathrm{mg} / \mathrm{L}, 2.5 \mathrm{mg} / \mathrm{L}$ and $1 \mathrm{mg} / \mathrm{L})$ and five lethal treatments $(120 \mathrm{mg} / \mathrm{L}, 60 \mathrm{mg} / \mathrm{L}$, $30 \mathrm{mg} / \mathrm{L}, 15 \mathrm{mg} / \mathrm{L}$ and $10 \mathrm{mg} / \mathrm{L}$ ) were used during the period of the experiment. The higher the concentration $(30 \mathrm{mg} / \mathrm{L}, 60 \mathrm{mg} / \mathrm{L}$ and $120 \mathrm{mg} / \mathrm{L})$ of paraquat, the higher the mortality $(0,1$ and 5$)$ by the end of $10 \mathrm{hr}$, thus the dose of the test chemical made the poison. Although herbicide such as paraquat can be used in the control of weed; biological and mechanical weed control methods are still better as they may pose little or no threat to the life of $T$. guinensis.
\end{abstract}

\section{DOI: https://dx.doi.org/10.4314/jasem.v23i7.5}

Copyright: Copyright $(\mathrm{C} 2019$ Nkeeh and Jamabo. This is an open access article distributed under the Creative Commons Attribution License (CCL), which permits unrestricted use, distribution, and reproduction in any medium, provided the original work is properly cited.

Dates: Received: 12 May 2019; Revised: 17 June 2019; Accepted 09 July 2019

Keywords: Acclimated, Tilapia guinensis, acute bioassay, paraquat and $\mathrm{LC}_{50}$

The rapid increase in human population has escalated the demand for quality food, like fish, in the world. To fulfill the food requirements, fish assume greater importance because, it contains high quality proteins, fats and minerals. Another feature of fish is its ability to convert raw materials into high quality proteins more efficiently than other terrestrial animals such as sheep, goats, cows etc. (Esmail et al., 2013). The growth in the production of crop globally, has been achieved through herbicide use. Nevertheless, aquatic living organisms can be adversely impacted, if the chemicals are used indiscriminately. It is a common practice in agriculture globally, to use herbicide in the control of weeds, mainly with the view of improving the production of agricultural products. Nevertheless, adverse effect can be seen on other organisms, other than the one intended as a result of indiscriminate use of herbicide in the environment, chiefly aquatic organisms (Nwani et al., 2011).

Paraquat is one of the most widely used herbicides in the world, controlling weeds in a huge variety of crops. Paraquat is used to control weeds before and after planting in more than 100 crops, including major food crops: corn, rice, soya, wheat, potatoes; major fruits: apples, oranges, bananas; beverages: coffee, tea, cocoa; and processed crops: cotton, oil palm, sugarcane, and rubber (PIC, 2017). In fruits such as sugar canes and pineapples paraquat serve a desiccative purpose (Tomlin, 1994). There has been noticeable increasing trend of aquatic organisms showing signs of fatigue and stress symptoms associated with the nature of the environment in which they live (Phys, 2014). The effect of stress in aquatic organisms includes; decrease stock and availability of fish for man, Poor quality of flesh, gasping for breath, rapidly breathing, or hanging at water surface, loss of appetite with attendant loss of weight, disease (Ich, characterized by white spots), strange swimming or swimming upside down, listless or laying at the bottom, slow to react to disturbances and stimuli, rubs against the aquarium glass and other surfaces. Most farmers resort to the use of herbicide in their integrated farms. This is because the use of mowers and other machines to remove weeds might be expensive. Thus, there is the need to research into the adverse effect of herbicide use. Aquatic organisms with fatigue and stress symptoms resulting from exposure to herbicide may not be productive to meet the increasing demand for aquatic food. This study is aimed at assessing the effect of paraquat on fingerlings of $T$. guinensis with the following objectives; to determine the $\mathrm{LC}_{50}$ of paraquat in T. guinensis and to assess the effect of paraquat on general growth and development parameters of tilapia fingerlings. 


\section{MATERIALS AND METHODS}

Test Organism

Fingerlings life specimen of $T$. guinensis, with mean weight of $40.20+2.35 \mathrm{~g}$ and mean length of $15.23+2.60 \mathrm{~cm}$ were used for toxicity test. The test organisms were obtained from (ARAC), African Regional Aquaculture Centre, Ikwerre Local Government Area, Rivers State, Nigeria. The test organisms were held in a suitable container with water and transported the same day to the Animal and Environmental Biology department laboratory, at the University of Port Harcourt, Choba, Rivers State. This developmental stage (fingerlings) of the test organism was chosen because of their high sensitivity and relative size.

Acclimation of the test organism: A total of 150 fingerlings of $T$. guinensis were kept at room temperature $28+2^{\circ} \mathrm{C}$ during the period of acclimation that lasted for 14days. The test organisms were fed with the fish feed obtained from the African Regional Aquaculture Centre, Omuihuechi, Aluu, Ikwere Local Government Area, Rivers State, Nigeria. They were acclimated in plastic tanks in which an aerator was used to continuously bubble air (oxygen). There was replacement of water in the acclimation units with tap water from the laboratory every 48 hours (2 days period). In the laboratory, there was a continuous lighting system throughout the acclimation period.

Test Chemical: Paraquat which is a well-known and widely used herbicide was utilized for the experiment. Commercial preparations of paraquat containing $200 \mathrm{~g} / \mathrm{L}$, was used as the stock solution for the study. This working stock was used to prepare range finding concentrations of paraquat $(120 \mathrm{mg} / \mathrm{L}, 60 \mathrm{mg} / \mathrm{L}$, $30 \mathrm{mg} / \mathrm{L}$ and $15 \mathrm{mg} / \mathrm{L})$. Also, the same working stock was used to prepare acute concentrations of paraquat (1mg/L, 2.5mg/L, $5 \mathrm{mg} / \mathrm{L}$ and $10 \mathrm{mg} / \mathrm{L})$.

Preparation of the Test Chemical: Equation (1) was used to prepare the chemical.

$\mathrm{V}_{1} C_{1}=\mathrm{V}_{2} C_{2} \ldots \ldots \ldots \ldots \ldots \ldots .1$

Where; $V_{1} C_{1}=$ Stock solution attributes; $V_{2} C_{2}=$ New solution attributes

Using the formulae above, the concentration and volume of paraquat for the range finding test was prepared thus; $120 \mathrm{mg} / \mathrm{L}(6 \mathrm{ml}), \quad 60 \mathrm{mg} / \mathrm{L}(3 \mathrm{ml})$, $30 \mathrm{mg} / \mathrm{L}(1.5 \mathrm{ml})$ and $15 \mathrm{mg} / \mathrm{L}(1 \mathrm{ml})$. Similarly, the concentration and volume of paraquat for the acute toxicity test was prepared thus; $10 \mathrm{mg} / \mathrm{L}(0.5 \mathrm{ml})$, $5 \mathrm{mg} / \mathrm{L}(0.25 \mathrm{ml}), \quad 2.5 \mathrm{mg} / \mathrm{L}(0.125 \mathrm{ml}) \quad$ and $1 \mathrm{mg} / \mathrm{L}(0.06 \mathrm{ml})$.
Selection of Test Organism: Five test organisms having relatively equal size were caught with the aid of a hand net randomly from tanks in which they were acclimated, which were later moved carefully into the treatment unit. Active and healthy test organisms were selected, and they were not handled with hand during the selection in order to avoid handling stress.

Range Finding Test: To establish an initial working range, Range Finding Test was conducted by using the least concentration leading to $100 \%$ death and the minimum concentration that resulted in no effect. The preliminary test was carried out by using multiple, usually widely spaced concentrations having double replication. The test organisms were exposed for $10 \mathrm{hr}, 12 \mathrm{hr}, 16 \mathrm{hr}, 20 \mathrm{hr}, 46 \mathrm{hr}, 48 \mathrm{hr}$ and $52 \mathrm{hr}$.

Experimental Design: Acute toxicity tests were conducted using T.guinensis by exposing them to various concentrations of the test chemical in solution. Similarly, chronic toxicity tests were carried out onthe test organisms by exposing them to various sublethal concentrations of the test chemical in solution. Both the acute and chronic toxicity tests were carried out using the static test procedure.

Mortality Responses: The basic criterion that was used to show mortality was total lack of movement. Thus, the test organisms were only confirmed dead when after been touched or pricked with an object, they remained motionless or immobile.

Statistical Analysis: Probit analysis (Finney, 1971) was used for the analysis of the mortality results. This was carried out in order to establish the LC50, of the test organism at different concentrations of the test chemical. Analysis of Variance (ANOVA) in SPSS version 16, was used for the significant analysis between test treatments and controls at $95 \%$ confidence limit.

\section{RESULTS AND DISCUSSION}

The dose-response curve is shown in Figure 1. From the dose-response curve, the higher the dose, the higher the mortality (response). Similarly, the mortality time-graph is shown in Figure 2. This current experiment reveal that the concentrations of paraquat $(60 \mathrm{mg} / \mathrm{L}, 30 \mathrm{mg} / \mathrm{L}$ and $15 \mathrm{mg} / \mathrm{L})$ resulted in a strong positive correlation coefficient $\left(\mathrm{R}^{2}=0.819, \mathrm{R}^{2}=0.737\right.$ and $R^{2}=0.820$ ), between mortality and time. From the mortality-time graph, for every increase in time there was a corresponding increase in mortality, thus exposing the test organisms for a longer time would result in more mortality. The result of this study showed that paraquat had significant effect on Tilapia guinensis. From the range finding test, after 6 hours of 
exposure of the test organism to paraquat, $30 \%$ (6 test organisms) died. Mortality continued to increase till the $52^{\text {nd }}$ hour, where $100 \%$ mortality $(20$ test organisms) of all exposed organisms was noticed. From the range finding test, it is evident that concentrations of paraquat $(60 \mathrm{mg} / \mathrm{L}, 30 \mathrm{mg} / \mathrm{L}$ and $15 \mathrm{mg} / \mathrm{L})$ resulted in strong positive correlation coefficients $\left(\mathrm{R}^{2}=0.819, \mathrm{R}^{2}=0.737\right.$ and $\left.\mathrm{R}^{2}=0.820\right)$, between mortality and time. However, at concentration of $120 \mathrm{mg} / \mathrm{L}$, there was neither correlation coefficient $\left(\mathrm{R}^{2}=\mathrm{N} / \mathrm{A}\right)$ nor linear equation $(y=0)$ between mortality and time. This might be due to the fact that the concentration $(120 \mathrm{mg} / \mathrm{L})$ was too high, and as such the test organisms died almost the same time.

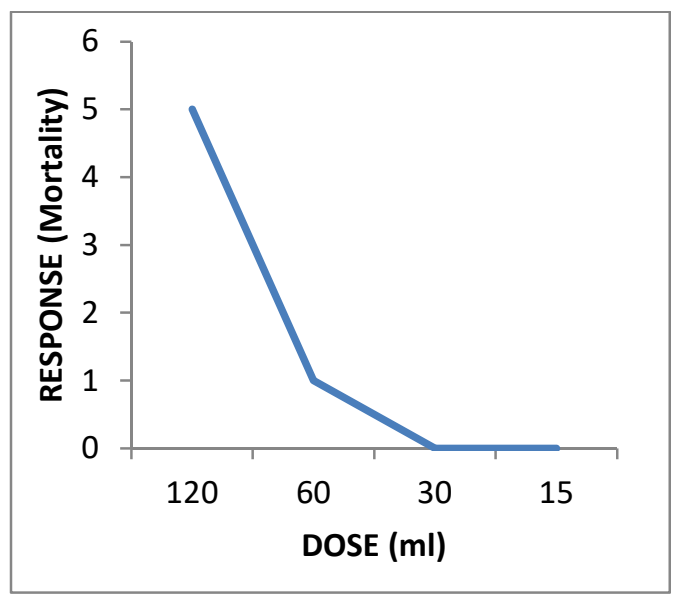

Fig 1. Dose response curve for T.guinensis

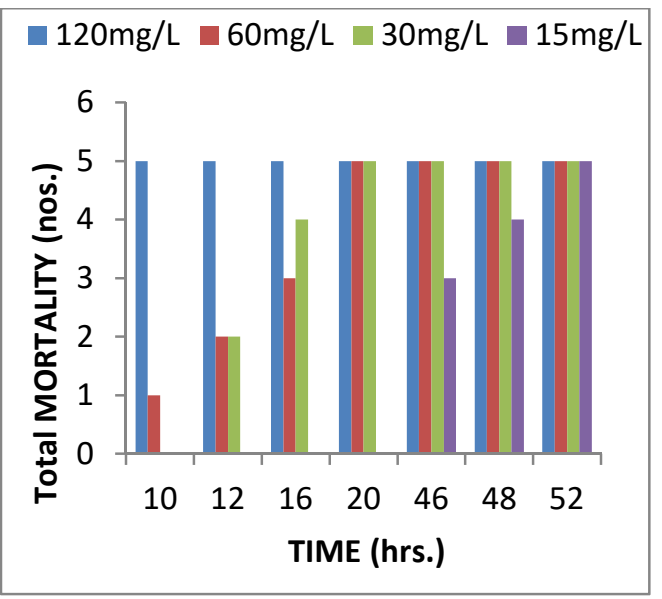

Fig 2. Mortality time graph for T. guinensis

The range finding test with immediate mortality as a consequence of paraquat application reveals that exposure of the test organism to high concentrations of paraquat, result in acute poisoning. This finding is in line with an earlier report by Tracil (2015), which stated that herbicides may cause harm by acute poisoning or long-term, cumulative exposure, with side effects ranging from mild to deadly. Landrum et al. (2006) had earlier reported low survival rate of earthworm when exposed to perchlorate. This is in agreement with the current research, as a low survival rate of $T$. guinensis was observed when the test organisms were treated with paraquat. From the acute toxicity test, by the end of 96hours, only the highest concentration of $10 \mathrm{mg} / \mathrm{L}$ recorded two mortalities, thus the other concentrations $(5 \mathrm{mg} / \mathrm{L}, 2.5 \mathrm{mg} / \mathrm{L}$ and $1 \mathrm{mg} / \mathrm{L}$ ) were sublethal. This shows one lethal treatment $(10 \mathrm{mg} / \mathrm{L})$ as against sublethal treatments $(5 \mathrm{mg} / \mathrm{L}, 2.5 \mathrm{mg} / \mathrm{L}$ and $1 \mathrm{mg} / \mathrm{L})$, which imply that the accumulation of paraquat at such concentration $(10 \mathrm{mg} / \mathrm{L})$ resulted in the death of the test organism. This result gives an idea of how the use of herbicide (paraquat) on the farm will result in the mortality of fish, which will in turn lower the profitability of the farm business. Unlike dramatic fish kills, the effects of sublethal concentrations of herbicides are more subtle and can go largely unnoticed, unreported and unregulated. This experiment show that herbicides in sublethal concentration do not cause immediate death however could interfere with the biology of the organism by other means which would ultimately impact the survival of the organism. It is the absence of immediate death that make farmers not realize the danger of applying herbicide on their farm. Holmes et al. (1994) had earlier reported sublethal concentrations of the herbicide, triclopyr butoxyethyl ester, in the diet of zebra finches. This result shows that the use of herbicide (paraquat) at such concentrations $(5 \mathrm{mg} / \mathrm{L}$, $2.5 \mathrm{mg} / \mathrm{L}$ and $1 \mathrm{mg} / \mathrm{L}$ ) might not lead to the death of the test organism and thus might go unnoticed. Earlier Kori-Siakpere et al. (2007), had also reported that two sublethal treatments $(0.15$ and $0.30 \mathrm{mg} / \mathrm{L})$ of paraquat and untreated (negative) control were tested for 96hours in a static system. These studies that show sublethal concentrations of paraquat, further validate the point that 'the dose makes the poison'.

The acute toxicity test also show that variation between the mortality of test organisms exposed to concentrations of paraquat $(30 \mathrm{mg} / \mathrm{L}$ and $15 \mathrm{mg} / \mathrm{L})$ are statistically significant $(\mathrm{p}<0.05, \mathrm{p}=0.0163553)$. This implies that the variation in mortality is as a result of a change in concentration of paraquat and not by chance or accident. In the same vein, the table also show that the difference between mortality of test organisms exposed to $30 \mathrm{mg} / \mathrm{L}$ and control was statistically significant $(\mathrm{p}<0.05, \mathrm{p}=0.00126)$, as was that between $60 \mathrm{mg} / \mathrm{L}$ and $15 \mathrm{mg} / \mathrm{L} \quad(\mathrm{p}<0.05$, $\mathrm{p}=0.008839$ ). However, the variation between the mortality of test organisms exposed to concentration of paraquat $(10 \mathrm{mg} / \mathrm{L}$ and Control) are not statistically significant $(p>0.05, p=0.090845)$. The acute toxicity test show that concentration of paraquat $(10 \mathrm{mg} / \mathrm{L})$ 
resulted in a strong positive correlation coefficient $\left(\mathrm{R}^{2}\right.$ $=0.8$ ), between mortality and time.

From the range finding test, values of $\mathrm{LC}_{50}$ were determined. The $\mathrm{LC}_{50}$ otherwise known as median lethal concentration is the concentration of the test chemical that would result in at least $50 \%$ mortality of the test organisms, within a specific time. From the study, $60 \mathrm{mg} / \mathrm{L}$ of paraquat will kill at least $50 \%$ of test organism, within 12 hours, $45 \mathrm{mg} / \mathrm{L}$ of paraquat administered to test organism within 16hours will kill at least $50 \%$ of test organism. Similarly, it will take 46 hours for $15 \mathrm{mg} / \mathrm{L}$ of paraquat to kill at least $50 \%$ of the test organism. And at least $50 \%$ of the test organism will be killed when exposed to paraquat at $15 \mathrm{mg} / \mathrm{L}$ within 48 hours. Also, within 66hours of exposure of the test organism to paraquat (at $10 \mathrm{mg} / \mathrm{L}$ ) at least $50 \%$ of the test organism will be killed. Similarly, $50 \%$ of the test organism exposed to paraquat at a concentration of $10 \mathrm{mg} / \mathrm{L}$, will be killed within 96hours. Thus, the 96hour $\mathrm{LC}_{50}$ was $10 \mathrm{mg} / \mathrm{L}$. Earlier $\mathrm{LC}_{50}$ has been reported by Correia et al. (2010), where it was stated that the $\mathrm{LC}_{50}$ of the herbicide, Fenamiphos, to earthworm Eiseniafoetida was $228 \mathrm{mg} / \mathrm{kg}$ soil. $\mathrm{LC}_{50}$ values have also been reported by Rombke et al. (2007), where it was noted that the $\mathrm{LC}_{50}$ of Benomyl (fungicide) to earthworm was $12.9 \mathrm{mg} / \mathrm{kg}$ soil.

Conclusion: Although herbicide such as paraquat can be used in the control of weed; biological and mechanical weed control methods are still better as they may pose little or no threat to the life of T.guinensis.

Acknowledgement: We wish to acknowledge the Department of Animal and Environmental Biology, University of Port Harcourt, Choba, Port Harcourt; for allowing us to use their laboratory for the experiment.

\section{REFERENCES}

Correia, FV; Moreira, JC (2010). Effects of glyphosate and 2, 4-D on earthworm (Eiseniafoetida) in laboratory tests. Bulletin of Environ. Contamination and Toxicol. 85: $264-268$.

Esmail, G; Hamed, N; Mohammad, RI; Vahid, T (2013). Effect of copper sulfate on the survival and growth performance of Caspian Sea Kutum, Rutilusfrisiikutum Springerplus. (2) : 498.

Holmes, SB; Thompson, DG; Wainio-Keizer, KL; Capell, SS; Stanzink, B (1994). Effects of lethal and sublethal concentrations of the herbicide, triclopyrbutoxyethyl ester, in the diet of zebra finches. J. Wildl. Dis. 30(3):319-27.

Kori-siakpere, O; Adamu, K; Okemabirhie, J (2007). Sublethal effects of paraquat on some plasma organic constituents (Metabolic parameters) of African catfish: Clariasgariepinus (OsteichthysClaridae). International Jour. of Zool. Research, 3:213-217.

Landrum, M; Canas, JE; Coibatorer, G; Cobb, GP; Jackson,WA; Zhang, B; Anderson, TA (2006). Effect of perchlorate on earthworm (Eiseniafoetida) survival and reproductive success. Sci. of Total Env., 63(1-3): 237-244.

Nwani, CD; Nagpure, NS; Kumar, R; Kushwaha, B; Kumar, P; Lakra, WS (2011). Mutagenic and genotoxic assessment of atrazine-based herbicide to freshwater fish Chana puntatus (Bloch) using micronucleus test and single cell gel electrophoresis. Env. Toxicol.Pharmacol. (31): 314-322.

Phys.org (2014), Effects of environmental stress on water organisms available at; Phys.org, accessed September,2017.

PIC (2017). Paraquat Information Center, available at paraquat.com, accessed Sept, $27^{\text {th }} 2017$.

Rombke, J; Garcia, MV; Scheffczyk, L (2007). Effect of the fungicide Benomyl on earthworm in laboratory tests under tropical conditions. Archives of Environ. Contamination and Toxicol. 53(4): 590-598.

Tomlin, C (1994). The Pesticide Manual incorporating The Agrochemicals Handbook, Tenth Edition, British crop protection council and the Royal Society of chemistry, Fanham UK.

Tracil, H (2015). Side effects of herbicides, Livestrong.com 